\title{
PENINGKATAN MUTU KERUPUK PANGAN LOKAL PADA USAHA RUMAH TANGGA DI DESA LINGGA, KUBU RAYA
}

\author{
Yohana Sutiknyawati Kusuma Dewi ${ }^{1 *}$, Oke Anandika Lestari ${ }^{2}$, Komariyati $^{3}$, \\ Deni Darmawan ${ }^{4}$ \\ ${ }^{1,2}$ Jurusan Budidaya Pertanian Prodi Ilmu dan Teknologi Pangan Universitas Tanjungpura, Pontianak \\ ${ }_{3}^{3}$ Jurusan Budidaya Pertanian Universitas Tanjungpura, Pontianak \\ ${ }^{4}$ Fakultas Fisip Universitas Tanjungpura, Pontianak \\ Jl. Prof. Dr. H. Hadari Nawawi, 78124 \\ Penulis Korespodensi : yohana@ps-itp.untan.ac.id
}

\begin{abstract}
The second year of Ipteks bagi Desa Mitra (IbDM) programs have been done at Lingga village Kubu Raya Regency. The aims of this programs were preparing of human resources able to produce cracker products according to SNI and its packaged with labels so that its was increasing of her family income. The target audience in the second year was a member of the PKKs of Lingga Dalam and Remaja Masjid group. The method was used evaluation and socialization, assistance, evaluation and monitoring. The cracker quality assurance is enhanced through production system by semimechanical cracker slicers and solar dryers. The two devices to produce crackers that its have uniform thickness and safety of contaminants during drying. Quality assurance is also carried out by enhancing the administration of both the production and marketing of crackers. The entire IbDM programs has an impact on improving the quality of products, partner income and consumer confidence.
\end{abstract}

Kata kunci: PPM, IbDM, Crackers, Lingga, quality

\section{Pendahuluan}

Kebijakan yang populer dikembangkan sampai abad dua puluh untuk meningkatkan pendapatan petani atau masyarakat perdesaan adalah meningkatkan nilai tambah hasil pertanian (Cowan, 2002). Dusun Lingga Dalam merupakan salah satu dusun di desa Lingga, kecamatan Sungai Ambawang, Kabupaten Kubu Raya Kalimantan Barat. Dusun ini dapat ditempuh dengan jalan darat menggunakan kendaraan roda dua dengan waktu tempuh selama 1.5 jam tetapi bila menggunakan speed maka waktunya hanya 1 jam dari tempat penyeberangan. Mayoritas dusun Lingga Dalam adalah suku madura. Organisasi sosial yang ada di dusun ini adalah PKK, remaja masjid dan kelompok pengajian. PKK dan remaja masjid menjadi mitra dalam kegiatan tim IbDM Universitas Tanjungpura Pontianak pada tahun kedua. Anggota PKK yang sudah berhasil melakukan usaha rumah tangga ada beberapa orang tetapi yang rutin bergerak dalam bidang pangan lokal ada 3 anggota. Usaha rumah tangga kerupuk pangan lokal merupakan salah satu produk olahan pangan yang berhasil dikembangkan di Desa
Lingga khususnya anggota PKK Dusun Lingga Dalam Kecamatan Ambawang Kabupaten Kubu Raya Kalimantan Barat melalui program IbDM pada tahun pertama (Dewi dkk., 2017). Pangan Lokal yang digunakan untuk membuat kerupuk tapioka adalah limbah kulit pisang dan pengembangan saat ini tidak hanya dengan kulit pisang tetapi juga dengan bahan tambahan kulit udang, udang, dan ikan bilis serta tersedia rasa alami. Saat ini anggota PKK yang membuat kerupuk sebagai usaha rumah tangga semakin bertambah walupun masih berskala kecil tetapi dapat menjadi sumber pendapatan baru (Dewi dkk., 2018). Kendala pengembangan usaha rumah tangga ini disebabkan kemampuan Sumber Daya Manusia (SDM) penguasaan teknologi masih rendah, mutu produk, dan pemasaran (Taib, 2014).

Menurut Taib dan Roswita (2018), pengembangan produk pangan harus didasarkan pada berbagai faktor, antara lain citarasa, keragaman produk, skala usaha, target pasar, kontinuitas bahan baku, kualitas SDM, modal usaha, manajemen usaha dan standar mutu. Standar mutu merupakan hambatan perkembangan produk 
usaha rumah tangga khususnya di perdesaan akibatnya daya saing rendah dan jangkauan pasar juga kecil. Mitra kegiatan IBDM salah satunya adalah PKK di dusun Lingga Dalam, pada tahun pertama kegiatan program IbDM berjalan hanya satu anggota yang secara serius mengebangkan kerupuk untuk dikomersialkan tetapi pada tahun kedua sudah menajdi 2 anggota.

Mitra menuturkan produksi kerupuk kulit pisang dan kerupuk pangan lokal lainnya mempunyai ukuran tidak seragam sehingga jumlah dalam persatuan berat tidak sama, rasa yang tidak stabil sehingga kandungan nutrisinya tidak sama. Semua kekurangan tersebut berdampak pada harga yang lebih murah dibandingkan yang sudah sesuai dengan Standar Nasional Indonesia serta mempunyai merk dan perijinan yaitu PIRT. Unit produksi masing-masing anggota PKK semua belum dilengkapi Standar Operasional Prosedur (SOP) baik produksi maupun pemasaran. Salah satu upaya peningkatan pendapatan keluarga maka usaha rumah tangga tersebut perlu ditingkatkan mutu produknya sehingga harga produk akhir tetap stabil. Upaya Tim IbDM dalam membantu mitra meningkatkan jaminan mutu kepada konsumennya, diantaranya menjaga keseragaman ukuran produk secara terus menerus melalui aplikasi alat, mempertahankan kualitas bahan baku dan proses sehingga kandungan nutrisi produk akhir stabil dan kontinuitas produksi.

Tujuan pelaksanakan pengabdian kepada masyarakat ini adalah mempersiapkan SDM mitra yang mampu memproduksi produk kerupuk pangan lokal menggunakan peralatan dan teknologi pangan sehingga menghasilkan mutu produk sesuai SNI dan dikemas dengan dilabel serta mampu menghasilkan pendapatan tambahan bagi keluarganya. Oleh karena itu fokus kegiatan yang dilakukan adalah: 1) Evaluasi mutu produk kerupuk mitra yang sudah berjalan; 2) Diseminasi Ipteks: pemanfaatan alat pemotong kerupuk semi mekanik dan pengering surya; 3) Pelatihan HKI dan tata kelola website; 4) Pendampingan pembuatan merk dan administrasi dan 5) Penyiapan persyaratan pengajuan ijin PIRT: analisis komposisi bahan dan produk kerupuk.

\section{Bahan dan Metode}

Kebijakan yang populer dikembangkan sampai abad dua puluh untuk meningkatkan pendapatan petani atau masyarakat perdesaan adalah meningkatkan nilai tambah hasil pertanian
(Cowan, 2002). Dusun Lingga Dalam merupakan salah satu dusun di desa Lingga, kecamatan Sungai Ambawang, Kabupaten Kubu Raya Kalimantan Barat. Dusun ini dapat ditempuh dengan jalan darat menggunakan kendaraan roda dua dengan waktu tempuh selama 1.5 jam tetapi bila menggunakan speed maka waktunya hanya 1 jam dari tempat penyeberangan. Mayoritas dusun Lingga Dalam adalah suku madura. Organisasi sosial yang ada di dusun ini adalah PKK, remaja masjid dan kelompok pengajian. PKK dan remaja masjid menjadi mitra dalam kegiatan tim IbDM Universitas Tanjungpura Pontianak pada tahun kedua. Anggota PKK yang sudah berhasil melakukan usaha rumah tangga ada beberapa orang tetapi yang rutin bergerak dalam bidang pangan lokal ada 3 anggota. Usaha rumah tangga kerupuk pangan lokal merupakan salah satu produk olahan pangan yang berhasil dikembangkan di Desa Lingga khususnya anggota PKK Dusun Lingga Dalam Kecamatan Ambawang Kabupaten Kubu Raya Kalimantan Barat melalui program IbDM pada tahun pertama (Dewi dkk., 2017). Pangan Lokal yang digunakan untuk membuat kerupuk tapioka adalah limbah kulit pisang dan pengembangan saat ini tidak hanya dengan kulit pisang tetapi juga dengan bahan tambahan kulit udang, udang, dan ikan bilis serta tersedia rasa alami. Saat ini anggota PKK yang membuat kerupuk sebagai usaha rumah tangga semakin bertambah walupun masih berskala kecil tetapi dapat menjadi sumber pendapatan baru (Dewi dkk., 2018). Kendala pengembangan usaha rumah tangga ini disebabkan kemampuan Sumber Daya Manusia (SDM) penguasaan teknologi masih rendah, mutu produk, dan pemasaran (Taib, 2014).

Menurut Taib dan Roswita (2018), pengembangan produk pangan harus didasarkan pada berbagai faktor, antara lain citarasa, keragaman produk, skala usaha, target pasar, kontinuitas bahan baku, kualitas SDM, modal usaha, manajemen usaha dan standar mutu. Standar mutu merupakan hambatan perkembangan produk usaha rumah tangga khususnya di perdesaan akibatnya daya saing rendah dan jangkauan pasar juga kecil. Mitra kegiatan IBDM salah satunya adalah PKK di dusun Lingga Dalam, pada tahun pertama kegiatan program IbDM berjalan hanya satu anggota yang secara serius mengebangkan kerupuk untuk dikomersialkan tetapi pada tahun kedua sudah menajdi 2 anggota. 
Mitra menuturkan produksi kerupuk kulit pisang dan kerupuk pangan lokal lainnya mempunyai ukuran tidak seragam sehingga jumlah dalam persatuan berat tidak sama, rasa yang tidak stabil sehingga kandungan nutrisinya tidak sama. Semua kekurangan tersebut berdampak pada harga yang lebih murah dibandingkan yang sudah sesuai dengan Standar Nasional Indonesia serta mempunyai merk dan perijinan yaitu PIRT. Unit produksi masing-masing anggota PKK semua belum dilengkapi Standar Operasional Prosedur (SOP) baik produksi maupun pemasaran. Salah satu upaya peningkatan pendapatan keluarga maka usaha rumah tangga tersebut perlu ditingkatkan mutu produknya sehingga harga produk akhir tetap stabil. Upaya Tim IbDM dalam membantu mitra meningkatkan jaminan mutu kepada konsumennya, diantaranya menjaga keseragaman ukuran produk secara terus menerus melalui aplikasi alat, mempertahankan kualitas bahan baku dan proses sehingga kandungan nutrisi produk akhir stabil dan kontinuitas produksi.

Tujuan pelaksanakan pengabdian kepada masyarakat ini adalah mempersiapkan SDM mitra yang mampu memproduksi produk kerupuk pangan lokal menggunakan peralatan dan teknologi pangan sehingga menghasilkan mutu produk sesuai SNI dan dikemas dengan dilabel serta mampu menghasilkan pendapatan tambahan bagi keluarganya. Oleh karena itu fokus kegiatan yang dilakukan adalah: 1) Evaluasi mutu produk kerupuk mitra yang sudah berjalan; 2) Diseminasi Ipteks: pemanfaatan alat pemotong kerupuk semi mekanik dan pengering surya; 3) Pelatihan HKI dan tata kelola website; 4) Pendampingan pembuatan merk dan administrasi dan 5) Penyiapan persyaratan pengajuan ijin PIRT: analisis komposisi bahan dan produk kerupuk.

\section{Hasil dan Pembahasan}

A. Evaluasi Produk Mitra Yang Sudah Berjalan dan Sosialisasi Kegiatan Tahun Berjalan

Menurut SNI, kerupuk merupakan produk makanan yang dibuat dari tepung pati dengan penambahan bahan lainnya dan bahan tambahan yang diijinkan. Kerupuk merupakan makanan ringan yang disukai semua kalangan dengan citarasa gurih, namun dengan berkembangnya teknologi dan kesukaan maka citarasa kerupuk berkembang dengan penambahan rempah dan bahan lainnya. Produk akhir kerupuk menunjukkan cita rasa dan aroma khas dari bahan yang digunakan demikian juga dapat mempengaruhi warna produknya.

Menurut Koswara (2009), kerupuk adalah suatu jenis makanan kering yang terbuat dari bahan-bahan yang mengandung pati cukup tinggi. Selanjutnya dikatakan pengertian lain menyebutkan bahwa kerupuk merupakan jenis makanan kecil yang mengalami pengembangan volume membentuk produk yang porus dan mempunyai densitas rendah selama proses penggorengan. Kerupuk merupakan produk ekstruksi yang akan mengalami pengembangan pada saat pengolahan. Berdasarkan pengertian di atas apabila dievaluasi maka produk kerupuk pangan lokal dari mitra anggota PKK yang berlokasi di dusun Lingga Dalam, menghasilkan cita rasa gurih yang merupakan cita rasa dasar kerupuk karena garam dan bumbu serta tekstur yang renyah karena adanya tambahan kulit pisang. Pada saat ini produksi kerupuk oleh mitra telah dikembangkan menjadi beberapa jenis kerupuk kulit udang, kerupuk udang, kerupuk ikan bilis selain yang sudah diintroduksikan pada awal kegiatan yaitu kerupuk kulit pisang dan kerupuk tapioka (original). Pada saat evaluasi mitra menyampaikan alasan menambah variasi jenis yaitu karena keinginan konsumen, tersediannya bahan baku yang melimpah dan keinginan produsen karena melihat promosi pada media sosial. Hasil produk kerupuk mitra sebelum aplikasi teknologi pangan untuk peningkatan mutu (gambar 1a.) dan kerupuk dipotong dengan alat pemotong semi mekanis (Gambar 1b).

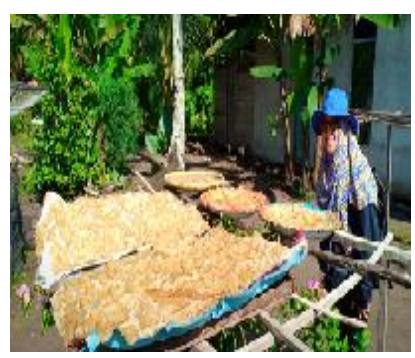

a. ProdukKerupuk

Sebelum Pendampingan

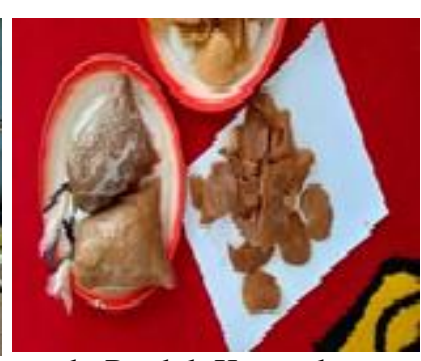

b. Produk Kerupuk Sesudah Pendampingan
Gambar 1 Produk mitra sebelum kegiatan

Hambatan yang terjadi pada mitra adalah persentase tinggi pada adonan kerupuk yang dibuang karena pada saat pemotongan ukuran tidak seragam. Pemotongan sebagian besar masih secara manual sehingga ukuran ketebalan tidak seragam dan jumlah kerupuk per satuan berat tidak sama akibatnya bahan adonan kerupuk banyak yang 
terbuang. Solusinya adalah perlunya perangkat teknologi pangan yaitu alat pemotong kerupuk semi mekanik. Pilihan teknologi ini berdasarkan pada karakter mitra dan latar belakang pendidikan.

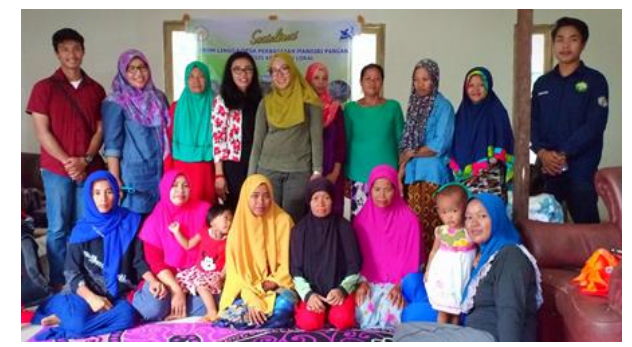

Gambar 2 Suasana sosialisasi kegiatan IbDM tahun berjalan
Sosialisasi kegiatan tahun berjalan merupakan tindak lanjut dari evaluasi yang dilakukan tim IbDM dengan mitra dan perwakilan dari kantor desa sebagai pendamping. Sosialisasi dilaksanakan dengan pendekatan FGD dan diakhiri dengan menyepakati masalah prioritas mitra yang akan diselesaikan serta kontribusi mitra, desa dan tim dalam penyelesaian masalah tersebut. Suasana sosialisasi disajikan pada gambar 2. Berdasarkan FGD maka kegiatan IbDM yang dilakukan untuk tahun berjalan yang berkaitan dengan kerupuk disajikan pada Tabel 1.

Tabel 1. Kegiatan IbBDM Desa Lingga yang terkait Sistem Jaminan Mutu Kerupuk

\begin{tabular}{|c|c|c|}
\hline No. & Kegiatan & Peserta/Pelaksana \\
\hline 1. & Evaluasi Produk Yang Sudah Berjalan dan Sosialisasi Kegiatan Tahun Berjalan & $\begin{array}{l}\text { Mitra, dan } \text { Perwakilan } \\
\text { Kantor Desa }\end{array}$ \\
\hline 2. & $\begin{array}{l}\text { Pelatihan dan pendampingan Pentingnya Sistem Jaminan Mutu Produk Olahan } \\
\text { Pangan Hasil Pertanian Pangan Lokal }\end{array}$ & $\begin{array}{l}\text { Mitra 1, 2, } 3 \text { dan Perwakilan } \\
\text { Kantor Desa }\end{array}$ \\
\hline 3. & $\begin{array}{l}\text { Perakitan Alat Pemotong Kerupuk dan Pendampingan Penggunaan dan Perawatan } \\
\text { Alat }\end{array}$ & $\begin{array}{lllll}\text { Mitra } & 1 & \text { dan } & 3 & \text { (Anggota } \\
\text { PKK) }\end{array}$ \\
\hline 4. & $\begin{array}{l}\text { Perakitan dan Pendampingan Penggunaan Alat Pengering Surya Sebagai Upaya } \\
\text { Jaminan Keamanan Produk Kerupuk }\end{array}$ & Mitra 1 dan 3 \\
\hline 5. & Pendampingan Administrasi Mitra & Mitra1 dan 2 \\
\hline 6. & $\begin{array}{l}\text { Koordinasi dan Pendampingan Tata Kelola Website Desa untuk Penyediaan Data } \\
\text { dan Pemasaran Produk Desa Lingga }\end{array}$ & $\begin{array}{l}\text { Mitra 2,3 dan Perwakilan } \\
\text { Desa }\end{array}$ \\
\hline 7. & $\begin{array}{l}\text { Pendampingan Persiapan Legalisasi Merk:Pelatihan dengan Dukungan dana Dari } \\
\text { Dinas UMKM Propinsi Kalimantan Barat }\end{array}$ & Mitra 1, dan 3 \\
\hline 8. & $\begin{array}{l}\text { Pendampingan Persiapan Legalisasi Produk untuk Pengajuan Perijinan PIRT: } \\
\text { Analisis Kandungan Bahan dan produk }\end{array}$ & Mitra 1, dan 3 \\
\hline 9. & Pemasaran Produk Kerupuk & Mitra 1.2 dan 3 \\
\hline 10. & Monitoring dan Evaluasi & Tim IbDM \\
\hline
\end{tabular}

\section{B. Diseminasi Teknologi Kerupuk}

Menurut Koswara (2009), tahapan pengolahan kerupuk terdiri dari pencampuran bahan baku, pembuatan adonan, pembentukan (berupa silinder), pengukusan, pendinginan, pengirisan, pengeringan dan penggorengan (untuk produk mentah cukup sampai proses pengeringan). Tahapan proses mempengaruhi mutu produk yang dihasilkan diantaranya adalah pengirisan adonan. Diseminasi teknologi untuk sistem jaminan mutu produk kerupuk dari anggota PKK Dusun Lingga Dalam meliputi alat pemotong kerupuk semi mekanik dan alat pengering surya. Masalah yang saat ini masih dialami oleh mitra adalah ukuran ketebalan yang tidak seragam dan mengakibatkan adonan banyak yang terbuang pada saat proses pengirisan kerupuk serta warna kusam dari kerupuk yang dikeringkan yang di duga pada saat penjemuran ada yang terkontaminasi karena di jemur secara terbuka.

Penggunaan alat pemotong semi mekanik pada mitra telah diinisiasi pada tahun pertama kegiatan IbDM tetapi aplikasi penuh dengan menambah satu alat pada mitra yang baru (mitra 3 yang pada tahun pertama masih bagian dari mitra 1), diharapkan masalah ukuran ketebalan kerupuk yang tidak seragam sudah tidak terjadi. Pada gambar 3, tampak anggota PKK dusun Lingga Dalam sudah mulai trampil menggunakan alat pemotong kerupuk dalam proses pengolahan kerupuk pangan lokal dan produk potongan yang dihasilkan lebih seragam ukurannya dan bahan adonan yang terbuang menjadi lebih sedikit. 

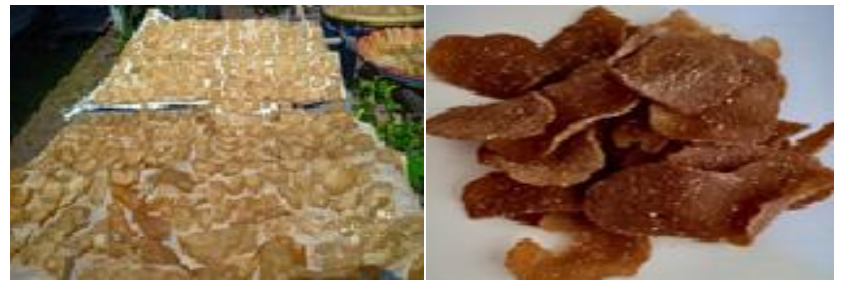

a. Pengeringan

b. Kerupuk dengan (penjemuran)

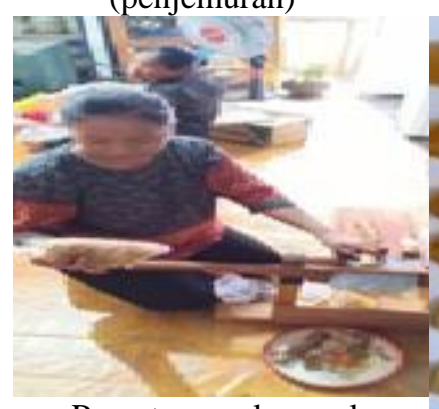

c. Pemotongan kerupuk dengan alat semi mekanik

d. Kerupuk hasil pemotongan dengan alat
dan produk kerupuk yang dihasilkan

Efisensi waktu dan bahan yang terbuang merupakan salah satu upaya yang diperjuangkan dengan adanya alat ini. Bahan adonan yang terbuang pada saat dipotong (manual) bisa mencapai 20 persen maka dengan menggunakan alat ini dapat menurunkan hingga 5-10\% bahan adonan terbuang. Namun demikian semua aplikasi alat dalam proses oleh mitra sangat dipengaruhi oleh karakter personal dan umur mitra. Pada mitra 1 yang sudah berumur di atas 50 tahun penggunaan alat belum rutin karena belum biasa dan cepat menyerah bila mengadapi kendala. Berbeda dengan mitra 3 yang terus berinovasi dan selalu rutin ketika sudah diberikan alat. Hal ini sesuai dengan pendapat Kartasapoetra (1989), yang mengatakan bahwa kemampuan petani dalam menerapkan inovasi teknologi dipengaruhi oleh umur, petani yang masih muda lebih cepat dalam mengadopsi sebuah inovasi teknologi dibanding yang tua karena semangat dan kekuatan fisik sudah menurun dan berkurangnya keberanian dalam menerima resiko.

Diseminasi teknologi yang kedua adalah penggunaan alat pengering surya. Pertimbangan tim terhadap diseminasi alat ini adalah hasil evaluasi dan persiapan persyaratan mitra untuk mengajukan PIRT. Sesungguhnya sulit sekali memilih kerupuk mentah yang bermutu baik. Menurut Koswara (2009), kriteria penilaian yang paling mungkin dilakukan adalah melihat warnanya, keseragaman atau homogenitas campuran bahan baku, baunya dan kekeringannya serta ada tidaknya jamur. Penilaian mutu kerupuk lebih mudah dilakukan pada kerupuk yang telah digoreng misalnya berdasarkan kerenyahannya, warnanya, rasanya dibandingkan dengan kerupuk mentah yang perlu analisis di laboratorium.

Perangkat alat pengering surya didiseminasikan sebagai upaya menjamin kemanan pangan kerupuk untuk sistem jaminan mutu. Kegiatan pengeringan kerupuk sebelumnya dengan menggunakan matahari yang dihampar pada plastik tanpa penutup sehingga kemungkinan terjadinya kontaminasi melalui udara sangat besar. Perangkat alat pengering surya diletakkan di halaman antara mitra 1 dan mitra sebagai produsen kerupuk saat ini. Detail alat pengering disajikan pada gambar 4 .

Penggunaaan alat ini dalam proses produksi mitra diharapkan meminimalisir kontaminan kerupuk sehingga mutu keamanan produk terjamin. Alat pengering surya terdiri dari 8 rak dan tiap rak dapat memuat 2-3 kilo kerupuk sehingga total dapat mengeringkan 18 kilo kerupuk dengan aman. Sebelumnya menggunakan plastik dan nampan sekali jemur kapasitas 3 kilo tetapi keamanan terhdap kontaminasi belum terjamin. Mutu kerupuk mitra yang baik merupakan salah satu upaya untuk meningkatkan daya saing. Monitoring dan Evaluasi merupakan salah satu upaya melihat kemajuan mitra dalam berproses sehingga kegiatan inilah yang selalu dilakukan oleh tim IbDM.

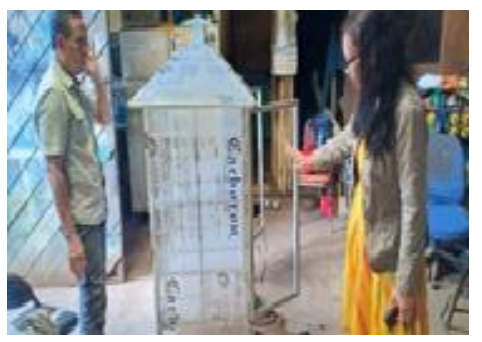

a. Proses perakitan alat pengering surya

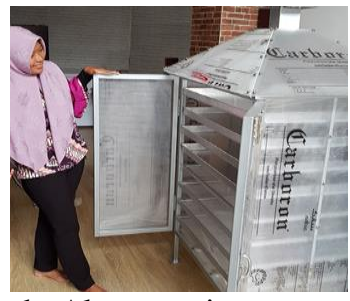

b. Alat pengring surya

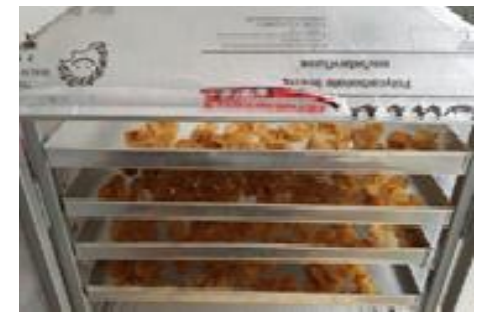

c. Aplikasi alat pengring surya pada produk kerupuk
Gambar 4. Alat pengering surya 


\section{Sistem Penjaminan Mutu Kerupuk}

Kerupuk merupakan produk olahan yang sangat populer dan secara mandatori telah mempunyai standar mutu yang ditetapkan oleh Departemen Perindustrian susai syarat mutu dan tertuang dalam SNI 01-2713-1992 yang disajikan pada Tabel 2.Produk kerupuk anggota mitra PKK dusun Lingga Dalam yang telah dianalisa adalah kerupuk kulit pisang dan kerupuk kulit udang. Kandungan nutrisi yang terdapat pada kerupuk kulit pisang telah memenuhi persyaratan SNI yaitu kadar Air $8,01 \%$, abu 0,94\%, protein 1,16\% dan karbohidrat $80,90 \%$. Kerupuk kulit udang produksi mitra juga sudah dilakukan uji kandungan nutrisi dan menghasilkan kadar air 7,0\%, lemak 13,87\%, serat kasar $0,74 \%$, protein $7,54 \%$, abu $3,41 \%$ dan karbohidrat $68,16 \%$. Berdasarkan hasil analisis kandungan nutrisi perlu adanya pembinaan lebih lanjut untuk produk kulit udang karena kandungan abu masih melewati batas yang diperbolehkan. Pendampingan lebih diarahkan pada modifikasi formulasi terutama jumlah kulit udang yang ditambahkan. Menurut Wowor dkk (2015), kandungan mineral kulit udang yang sudah ditepungkan mengandung kalsium sebanyak 2,98 $\%$ dan fosfor $0,898 \%$. Kandungan mineral yang tinggi apabila ditambahkan dalam formulasi adonan kerupuk berpengaruh pada kandungan abu produk akhir, hal ini tentu menjadi pertimbangan tim untuk mendampingi dalam modifikasi formulasinya sehingga memenuhi syarat mutu SNI.

Tabel 2 Syarat mutu kerupuk menurut SNI

\begin{tabular}{|c|c|c|}
\hline Kriteria Uji & $\begin{array}{l}\text { Persayaratan Keupuk } \\
\text { Non protein }\end{array}$ & Persyaratan Kerupuk Protein \\
\hline Bau, Rasa, Warna & Normal & **Khas sesuai sumber protein \\
\hline Benda Asing $(\%, b / b)$ & Tidak nyata & Tidak nyata \\
\hline Abu $(\%, b / b)$ & Maksimal 2 & Maksimal 2 \\
\hline $\operatorname{Air}(\%, b / b)$ & Maksimal 12 & Maksimal 12 \\
\hline Protein $(\%, b / b)$ & - & Minimal 5 \\
\hline Serat $\operatorname{Kasar}(\%, \mathrm{~b} / \mathrm{b})$ & Maksimal 1 & Maksimal 1 \\
\hline $\begin{array}{l}\text { Serangga dalam bentuk stadia dan } \\
\text { potongan benda-benda asing }\end{array}$ & Tidak nyata & Tidak nyata \\
\hline Kapang & Tidak Nyata & Tidak nyata \\
\hline Bahan Tambahan Makanan & $\begin{array}{l}\text { Tidak nyata atau sesuai aturan } \\
\text { yang berlaku }\end{array}$ & $\begin{array}{l}\text { Tidak nyata atau sesuai aturan yang } \\
\text { berlaku }\end{array}$ \\
\hline $\begin{array}{l}\text { Logam-logam berbahaya }(\mathrm{pb}, \mathrm{Cu}, \mathrm{Hg}) \\
\text { dan As }\end{array}$ & $\begin{array}{l}\text { Tidak nyata atau sesuai aturan } \\
\text { yang berlaku }\end{array}$ & $\begin{array}{l}\text { Tidak nyata atau sesuai aturan yang } \\
\text { berlaku }\end{array}$ \\
\hline
\end{tabular}

*Sumber: Badan Standarisasi Nasional (1992)

**Keterangan:khas misal kerupuk ikan rasa ikan

Kendala lainnya adalah kerupuk yang saat ini dibuat belum dibuat label baik yang mentah maupun yang matang demikian juga perijinan PIRT sehingga kondisi ini menjadi kendala untuk pemasaran pada skala besar dan jangkauan yang lebih luas dan berdampak pada nilai tambah.

\section{Pendampingan Adminstrasi Mitra dan Tata kelola Wsite}

Pembukuan merupakan faktor hambatan yang paling besar bagai usaha rumah tangga seperti mitra. Hal ini juga dirasakan oleh tim IbDM walaupun sudah satu tahun berjalan tetapi untuk melakukan secara rutin masih sulit. Hal inilah yang selalu dilakukan terus oleh tim sehingga kebiasaan pembukuan bukan lagi menjadi hal yang berat. Suasana pendampingan administrasi kepada mitra di susun Lingga Dalam Desa Lingga, Kecamatan Ambawang, Kabupaten Kubu Rayaseperti disajikan pada gambar 5 .



Gambar 5 Pendampingan administrasi pada mitra

Tata kelola website desa Lingga merupakan tanggung jawab desa dan mitra 2 yaitu kelompok remaja masjid. Tahun pertama salah satu anggota mitra 2 sukses dengan cabe rawit dan sudah 
dipasarkan hingga Kota Pontianak tetapi bencana hama lalat buah menyerang dan semua tanaman mati yang berjumalah 4000an tanaman. Pada saat ini lahan di coba diganti dengan menanam talas dan belum berproduksi sehingga tidak dilakukan pendampingan komoditi. Koordinasi pada saat pendampingan dengan salah satu anggota mitra dua dan laman web disajikan pada gambar 6 .

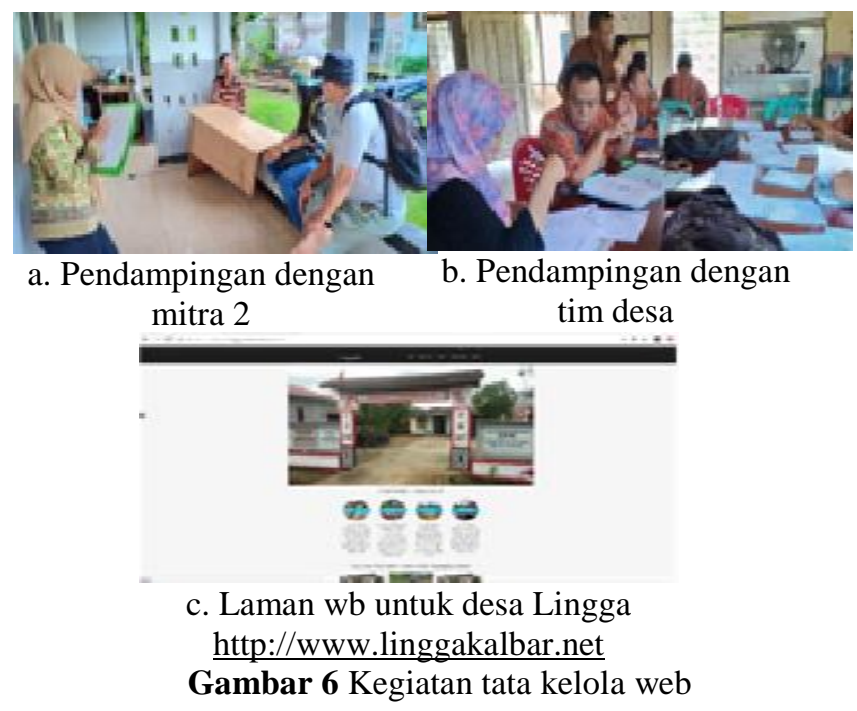

\section{E. Pendampingan Legalisasi Merek Dagang}

Legalisasi merek dagang diharapkan menjadi salah satu parameter mutu yang akan dimiliki oleh mitra IbDM dalam usaha kerupuk pangan lokal. Pada saat ini pengetahuan tentang pentingnya merek oleh mitra belum diketahui sehingga tahapan yang dimulai oleh tim IbDm dengan mengikutsertakan mitra dalam pelatihan HKI. Pelatihan HKI ini merupakan dukungan dari Dinas IKM Propinsi terhadap kegiatan ini dengan harapan mitra dapat menindaklanjuti dengan permohonan kekayaan intelektual berupa merek. Dokumentasi keikutsertaan mitra disajikan pada gambar 7 .

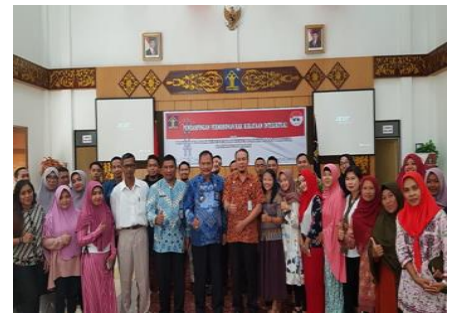

Gambar 7 Pelatihan HKI untuk persiapan legalisasi Merk Kerupuk

\section{F. Pendampingan Pemasaran Produk}

Produk kerupuk pangan lokal yang diproduksi mitra 1 dan mitra 3 dijual untuk memenuhi konsumen di sekitar desa Lingga. Penjualan dalam bentuk mentah dikemas dengan plastik sesuai pesanan tetapi untuk yang penjualan kerupuk siap saji dengan kemasan kecil dengan sistem konsinyasi di warung--warung yang ada di Lingga. Kerupuk mentah dijual dengan harga $\mathrm{Rp} 30.000$ per kilo sedangkan yang matang dengan kemasan kecil harga Rp 1000,- per kemasan. Mitra 1 dapat menjual 5-8 $\mathrm{kg}$ per minggu kerupuk mentah sedangkan untuk mitra 3 mampu memasarkan kerupuk mentah sebanyak $10-15 \mathrm{~kg}$ per minggu dan kerupuk matang 50-75 bungkus per hari. Kedua mitra saat ini belum mempunyai karyawan tetapi sebenarnya dalam berkegiatan produksi ada anggota keluarga yang kadang-kadang membantu terutama dalam proses produksi. Mitra saat ini merasa lebih percaya diri dan memberikan informasi kepada konsumen sehingga kepercayaan konsumen menjadi meningkat dengan sistem produksi yang saat ini diterapkan.

\section{G. Evaluasi dan Monitoring}

Evaluasi dan monitoting merupakan upaya tim untuk melihat perkembangan mitra dan sekaligus mengevaluasi kekurangan dalam proses kegiatan selama tahun berjalan sehingga dapat dilakukan perbaikan untuk tahun yang akan datang. Sebelum dan sesudah kegiatan IbDM dilakukan pengisian kusisioner untuk mengetahui kemampuan serapan mitra dan anggotanya serta keinginan produk yang dipilih untuk dikembangkan lebih lanjut serta manfaat kegiatan secara keseluruhan. Hasil rekapitulasi kuesioner yang telah disebarkan pada kegiatan, dengan kesimpulan untuk manfaat pilihan pengembangan adalah sebagai berikut disajikan pada Tabel 3. Kuisioner disebarkan baik pada pelaku langsung dari anggota PKK yang sudah produksi maupun yang anggota biasa serta tim pendamping desa. Kuisioner disebarkan pada 10 orang.

Tabel 3 Manfaat pilihan pengembangan produk

\begin{tabular}{llll}
\hline $\begin{array}{l}\text { Jawaban } \\
\text { (orang/\%) }\end{array}$ & Tepung & Mi & Kerupuk \\
\hline $\begin{array}{l}\text { Sangat } \\
\text { Berguna }\end{array}$ & $1(10)$ & $4(40)$ & $5(50)$ \\
$\begin{array}{l}\text { Berguna } \\
\text { Kurang }\end{array}$ & $0(0)$ & $4(40)$ & $6(50)$ \\
$\begin{array}{l}\text { Berguna } \\
\text { Tidak Berguna }\end{array}$ & 0 & 0 & 0 \\
\hline
\end{tabular}




\begin{tabular}{llll} 
Menambah & 2 & 1 & 7 \\
Penghasilan & & & \\
\hline
\end{tabular}

Berdasarkan Tabel 3, maka kegiatan IbDM khususnya tahun kedua menunjukkan bahwa Masyarkat mitra dan pendamping desa setuju untuk tetap mengembangkan kerupuk dan mie tetapi secara manfaat produk kerupuk sangat berguna dibanding mi pangan lokal karena cepat dikembangkangkan dalam bentuk usaha dan menambah pendapatan keluarga. Hal ini diduga karena kerupuk merupakan makanan yang sudah populer dan tahan disimpan lama dibanding mi. Mi pada sat ini masih lebih familiar mi instan sehingga sosialisasi dan temu usaha dapat dilakukan pada kegiatan yang akan datang. Mi pangan lokal oleh anggota mitra menjadi kombinasi dengan kerupuk pada saat dijual dengan satu paket hidangan pada acara tertentu.

\section{Kesimpulan}

Pelaksanaan pengabdian kepada masyarakat melalui program IbDM tahun kedua di desa Lingga kecamatan Sungai Ambawang kabupaten Kubu Raya Kalimantan Barat dapat meningkatkan sistem jaminan mutu mitra produsen kerupuk pangan lokal. Metode pendekatan yang diaplikasikan adalah evaluasi produk yang sudah berjalan, sosialisasi teknologi yang diterapkan, pendampingan, evaluasi dan monitoring. Sistem jaminan mutu produk kerupuk ditingkatkan melalui penggunaan alat produksi kerupuk berupa pemotong kerupuk semi mekanik dan pengering surya. Penggunaan kedua alat tersebut sebagai upaya meningkatkan keseragaman ketebalan kerupuk dan keamanan terhadap kontaminan selama pengeringan. Penjaminan mutu juga dilakukan dengan peningkatan sistem administrasi baik produksi maupun pemasaran kerupuk oleh mitra. Keseluruhan kegiatan IbDM berdampak pada peningkatan mutu dan kuantitas produk kerupuk, pendapatan mitra dan kepercayaan konsumen.

\section{Ucapan Terima Kasih}

Penulis mengucapkan terimakasih kepada Direktorat Riset dan Pengabdian Masyarkat (DRPM), Kementerian Riset, Teknologi dan pendidikan Tinggi yang telah memberikan dana ibah untuk pelaksanaan kegiatan IbDM melalui DIPA UNTAN dengan surat kontrak No 015/SP2H/PPM/DRPM/2018 Tanggal 15 Februari 2018

\section{Daftar Pustaka}

Badan Standar Nasional. 1992. SNI 01-2713-1992. Kerpuk Ikan. Badan standarisasi nasional Indonesia. Jakarta.

Cowan, T. 2002. Value-Added Agricultural Enterprises in Rural Development Strategis. Visiting Scholar in Economic Growth and Enterpreneurship Resource, Science, and Industry Division.. Congressional Research Service. The Library of Congress. Repot for Congress .

Dewi, Y.S.K., O. A. Lestari, Komariyati, dan Sarmila. 2017. Laporan Akhir Ipteks Bagi Desa Mitra "Lingga Desa Perbatasan Mandiri Pangan". Tidak dipublikasikan (Perpustakaan LPPKM UNTAN)

Dewi, Y.S.K., O. A. Lestari, Komariyati, dan D. Darmawan. 2018. Laporan kemajuan Ipteks Bagi Desa Mitra "Lingga Desa Perbatasan Mandiri Pangan". Tidak dipublikasikan (Perpustakaan LPPKM UNTAN)

Kartasapoetra. 1988. Teknologi Penyuluhan Pertanian. Jakarta: CV. Yasaguna.

Taib, G., Santosa, M. Djalal, dan Helmi. 2014. Evaluation in Component Technology Small Scale Food Industry Cluster in West Sumatra. International Journal on Advanced Science, Engineering and Information Technology. Vol. 5(2): 25-27.

Wowor, A.R.Y., B. Bagas, L. Untu, H. Liwe. 2015. Kandungan Protein Kasar, Kalsium dan Fosfor Tepung Limbah Udang sebagai Pakan yang Diolah dengan Asam Asetat. Zootrek Journal.

35(1):1-9. 